\title{
Preliminary results of palynological investigation of lakes bottom sediments from Pechora Delta River
}

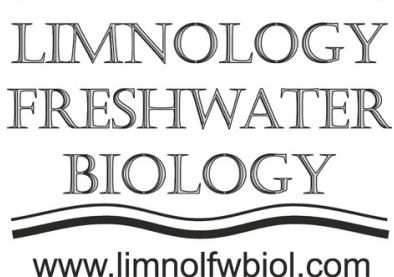

\author{
Nigamatzyanova G.R., Frolova L.A., Nigmatullin N.M. \\ Kazan Federal University, Kremlevskaya Str., 18, Kazan, 420008, Russia
}

\begin{abstract}
We studied spore-pollen spectrum of the arctic lake Arcto-Pimberto (Pechora river delta, Nenets Autonomous Okrug, Russian Arctic) from a short sediments core covering last ca. 6000 years. In total, 28 pollen and spore taxa have been identified. The spore-pollen spectrum from the sediments were dominated by arboreal taxa. Pollen of Betula sp., Cyperaceae and Sphagnum spore were present throughout the core in relatively constant percentages. Four palynological zones are definable under consideration on the basis of the spore-pollen data (PZ I - PZ IV). The spore-pollen spectra from the PZ I are characterized by a prevailing share of arboreal taxa pollen mostly represented by Betula spp., Salix, Alnaster with the presence of heather (Ericaceae) communities. The PZ I was deposited in wetter conditions. The spore-pollen spectra from the middle layers of the core (PZ II - PZ III) are characterized by an increased concentration of herbaceous taxa pollen. The climate was more arid. The pollen spectrum from the PZ IV reflects the development of moss and low-growing shrubs in wet climates.
\end{abstract}

Keywords: pollen, spore, tundra, Arctica, Nenets Autonomous Okrug

\section{Introduction}

Considering the sensitivity to climate change the study of Arctic ecosystems is particularly important for investigation on past and present climaterelated and environmental changes (Frolova, 2018; Frolova et al., 2017). Biological proxy data from lake sediments can provide unique data on recent changes (Nigamatzyanova et al., 2019; Zinnatova, Frolova, Nurgaliev, 2019). The aim of this work was to conduct the spore-pollen analysis and to identify vegetation cover changes in the catchment area of the arctic lake Arcto-Pimberto (Pechora river delta) under the changing climatic conditions at last 6000 years.

\section{Material and methods}

Arcto-Pimberto Lake $\left(68^{\circ} 26^{\prime} \mathrm{N}, 53^{\circ} 32\right.$ E) is located $90 \mathrm{~km}$ away from Naryan-Mar on the territory of the Nenets Nature Reserve. The climate of the region is continental (Frolova, Nigmatullin, Frolova, 2019). Landscapes are represented by lichen shrub tundra, depression marshes and moss-shrub-lichen vegetation (Lukin, Dauvalter, Novoselov, 2000). 25 samples from $96 \mathrm{~cm}$ long sediment core of the lake have been recovered for the palynological analysis using standard procedure according Faegri-Iversen method (Faegri, Iversen, 1989). One lycopodium spore tablets per samples used to calculate the total pollen and spore concentrations.
Percentages of pollen have been calculated based on a total sum of all pollen taxa taken as $100 \%$. Tilia/ TiliaGraph software and CONISS have been used for a visual representation of the palynological analysis results (Grimm, 2004).

\section{Results and discussions}

In total 8 arboreal taxa, 16 non-arboreal taxa pollen and 4 spore taxa have been identified. The dominance of arboreal pollen has been revealed throughout the core. Four pollen zones (PZ I - PZ II) have been distinguished. Vegetation cover was represented by low-growing shrubs (Betula spp., Salix, Alnaster) with the presence of heather (Ericaceae) and moss (Sphagnum) communities during the deposition of the PZ I (95-78 cm) in humid conditions in the end of Atlantic period (Khotinskij N.A., Nemkova V.K., Surova, 1982). The PZ II $(78-46 \mathrm{~cm})$ revealed a decrease of an arboreal pollen share and an increase of non-boreal pollen percentage. During the deposition of PZ II the climate was colder and dryer. Spore-pollen spectrum of the PZ III $(46-26 \mathrm{~cm})$ revealed a continuing decline of arboreal pollen content and increase of herbaceous pollen. Climate aridization continued in Subboreal and Subatlantic periods. The vegetation cover of the PZ IV $(26-0 \mathrm{~cm})$ indicates the development of modern vegetation in the humidification of the region's climate.

*Corresponding author.

E-mail address: gulnaraniga@mail.ru (G.R. Nigamatzyanova) 


\section{Conclusions}

The development of low-growing shrubs with the presence of heather community in a humid climate, followed by the development of various grasses due to aridization and re-development of low-growing shrubs with heather and moss due to climate humidification was revealed over the past 6 thousand years in the catchment area of the lake Arcto-Pimberto.

\section{Acknowledgements}

The laboratory work was funded by the Russian Foundation for basic research (projects no. 18-0500406, 19-05-50014).

The creation of the regional database of surface sediments of tundra lakes was funded by the grant from the Russian science Foundation (project no. 2017-00135).

\section{References}

Frolova L., Nazarova L., Zinnatova E. et al. 2017. Cladocera remains from sediments of thermokarst lakes of north-central Siberia (Russia). $17^{\text {th }}$ International Multidisciplinary Scientific GeoConference SGEM 2017, Conference Proceedings 17(51): 211-218. https://doi.org/10.5593/sgem2017/51/S20.028
Frolova L., Nigmatullin N., Frolova A. 2019. First record of Phreatalona Protzi (Hartwig, 1900) (branchiopoda: Anomopoda) in a tundra lake in north-east European Russia, International Multidisciplinary Scientific GeoConference Surveying Geology and Mining Ecology Management, SGEM 19(5.1): 285-290. DOI:10.5593/sgem2019/5.1/S20.036

Frolova L.A. 2018. Cladocera from bottom deposits as an indicator of changes in climate and ecological conditions. IOP Conference Series: Earth and Environmental Science 107(1): 012084. https://doi.org/10.1088/1755-1315/107/1/012084

Grimm E. Tilia software 2.0.2. 2004. Illinois State Museum Research and Collection Center, Springfield.

Khotinskij N.A., Nemkova V.K., Surova T.G. 1982. The main stages of development of vegetation and climate of the Urals in the Holocene. Archaeological studies of Northern Eurasia: 145-153 (in Russian)

Lukin A.A., Dauvalter V.A., Novoselov A.P. 2000. Ecosystem of the Pechora river in modern conditions, Apatity: Kola science centre Russian Academy of sciences. (in Russian)

Nigamatzyanova G.R., Frolova L.A., Kadirov A.G., Nurgaliev D.K. 2019. Vegetation Changes during the Holocene Inferred from Pollen Study of Lake Rubskoe Bottom Sediments (European Russia), Paleontological Journal, Russia 53: 787-789. DOI: 10.1134/S0031030119080136

Zinnatova E., Frolova L., Nurgaliev D. 2019. Diatom complexes in the bottom sediments of big Miassovo lake (South Ural, Russia), International Multidisciplinary Scientific GeoConference Surveying Geology and Mining Ecology Management, SGEM 19(5.1): 181-188. DOI:10.5593/ sgem 2019/5.1/S20.023 